\title{
The Rich World of p53 DNA Binding Targets: The Role of DNA Structure
}

\author{
Václav Brázda * (D) and Miroslav Fojta \\ Institute of Biophysics of the Czech Academy of Sciences, Královopolská 135, 61265 Brno, Czech Republic; \\ fojta@ibp.cz \\ * Correspondence: vaclav@ibp.cz; Tel.: +420-541-517-231
}

Received: 11 October 2019; Accepted: 8 November 2019; Published: 9 November 2019

\begin{abstract}
The tumor suppressor functions of p53 and its roles in regulating the cell cycle, apoptosis, senescence, and metabolism are accomplished mainly by its interactions with DNA. p53 works as a transcription factor for a significant number of genes. Most p53 target genes contain so-called p53 response elements in their promoters, consisting of $20 \mathrm{bp}$ long canonical consensus sequences. Compared to other transcription factors, which usually bind to one concrete and clearly defined DNA target, the p53 consensus sequence is not strict, but contains two repeats of a $5^{\prime}$ RRRCWWGYYY $3^{\prime}$ sequence; therefore it varies remarkably among target genes. Moreover, p53 binds also to DNA fragments that at least partially and often completely lack this consensus sequence. p53 also binds with high affinity to a variety of non-B DNA structures including Holliday junctions, cruciform structures, quadruplex DNA, triplex DNA, DNA loops, bulged DNA, and hemicatenane DNA. In this review, we summarize information of the interactions of p53 with various DNA targets and discuss the functional consequences of the rich world of p53 DNA binding targets for its complex regulatory functions.
\end{abstract}

Keywords: p53; protein-DNA interactions; consensus sequence; cruciform; local DNA structures

\section{Introduction}

p53 is the most often mutated tumor suppressor in humans and is studied intensively from different points of view due to its crucial role in malignant transformation [1-3]. p53 functions include regulatory roles in processes such as ontogenesis [4-6], myogenesis [7], metabolism [8], cell cycle arrest [9,10], apoptosis [11,12], angiogenesis [13,14], DNA repair [15,16], and cell senescence [16,17]. These numerous roles are realized through its interactions with other proteins and DNA. Although p53 mediated gene transcription is mostly connected to its direct interaction with DNA, it has also been shown that p53 interacts with many proteins, including several transcription factors and regulators [18]. Especially for mutant p53, its transcriptional functions relate to its ability to interact with other transcription factors [19]. Both activation, for NF-Y [20], or repression, for p63 and p73 [21,22], has been demonstrated. However, many other transcription factors interact with p53 [23]. p53 plays roles in multiple pathways [24-26] by acting as a transcription factor, therefore requiring DNA binding activity [27-29]. Compared to many other transcription factors, p53 DNA targets are not defined by a particular consensus sequence, but p53 is able to bind various DNA sequences and DNA targets defined by their secondary structures. Many of these local DNA structures are conserved throughout evolution and play essential roles in regulating many biological processes [30-32]. There are several types of these "alternative" DNA structures such as cruciforms, left-handed DNA (Z-DNA), triplexes and quadruplexes $[33,34]$. Bioinformatic analyses demonstrated non-random locations within the genome for certain local DNA structures, for example origins of replication (cruciforms), promoter regions (cruciforms, triplexes, and G-quadruplexes), introns (triplexes) and telomeres (G-quadruplexes) [35-41]. 
In keeping with their important regulatory roles, many local DNA structures are important also in human diseases, for example triplex structure in the frataxin gene caused by GAA/TTC triplet expansion is associated with Friedreich's ataxia [42,43]. Many studies have also shown dysregulation of local DNA structures in cancer cells and especially G-quadruplexes are being tested as a target for cancer treatment $[44,45]$. The interactions of p53 with DNA target sequences have recently been reviewed in several papers [2,46-52], including detailed analyses of the p53 family consensus sites and its non-canonical sequences with different lengths, variations of the core and flanking sequences and spacers (see below) [53]. Therefore, in this review, we focus on p53 binding properties to DNA targets in non-B-DNA conformation and to local DNA structures. We summarize published data about these interesting p53 DNA binding properties and hypothesize their possible roles.

\section{Various DNA Targets of p53}

\subsection{ChIP-Seq and p53-Target Sequences}

DNA sequence-specific binding of p53 was initially determined by the SELEX method and has been verified by many approaches in vitro and in vivo [54,55]. Complete mutagenesis of the p53 DNA target, which is typically formed by two copies of a $5^{\prime}$-RRRCWWGYYY-3' sequence (where R represents purine, $\mathrm{Y}$ represents pyrimidine and $\mathrm{W}$ represents adenine or thymine bases), provides information concerning p53 binding affinities for all possible consensus p53 targets and it is easy to compute the theoretical p53 binding affinity to the target in its linear B-DNA form [56,57]. p53 is also able to search for its target by sliding $[29,58,59]$ and can promote intersegmental transfer by binding to two DNA strands simultaneously [60]. Contemporary analyses of datasets from genome-wide chromatin immunoprecipitation (ChIP) of p53-bound DNA fragments followed by high-throughput sequencing has led to the development of p53 BAER (a human p53 Binding And Expression Resource) [61] that can be accessed on the University of California Santa Cruz (UCSC) Genome Browser [62,63]. These complex analyses confirmed and validated some known data about p53 sequence-specific DNA binding and p53 consensus sequence(s), showing, for example, that the most common is the consensus sequence without spacers and that many precipitated fragments contain only half of the consensus sequence [61]. In addition, these analyses brought many new and unexpected results. For example, only $35 \%$ of the sequences are in the range of $5 \mathrm{kbp}$ before the transcription start site (TSS), while $25 \%$ are found in intragenic and $41 \%$ in intergenic regions. Assuming that the main role of p53 is associated with transcription, it could be expected that the majority of p53-target sequences will be found in promoter regions. Therefore, the above-mentioned results provoke the question: what is the role of p53 binding to regions which are far away from TSS and therefore could hardly regulate transcription?

Based on homology with the consensus binding site or the presence of half-binding sites, it is possible to predict potential p53 binding sites in the human genome and their theoretical affinities and several tools are available for these purposes $[56,57,64]$. Using this approach, almost 800,000 potential p53 target sequences containing a p53-like motif consisting of the p53 consensus 20-mer with a 0-15 bp spacer or with only a half-site have been identified in the human genome [48]. However, data from 41 ChIP datasets identify only 54,947 p53-bound sequences, of which just 12,885 (23\%) contain either a full or half-site p53 consensus sequence [61]. Thus, from all of the predicted potential p53 targets in the human genome (almost 800,000 ), only $\sim 1.6 \%$ are actually bound by 553 and most p53-bound DNA fragments $(77 \%)$ do not contain a consensus binding site. From these analyses, it is clear that multiple factors are required to enable p53 binding to DNA. Moreover, what does p53 protein recognize in the genome when the classic p53 double-stranded B-DNA target sequence is not present? Interestingly, a substantial correlation exists amongst the p53 ChIP-seq data and the presence of CpG islands [61,65]. Moreover, many studies have now demonstrated that p53 binds to various non-B DNA targets, as reviewed below. 


\section{2. p53 Binding to Distorted Double-Stranded DNA}

The majority of DNA exists in the double-stranded form in the genomes of both prokaryotic and eukaryotic organisms. However, DNA is a structurally flexible molecule and exists also in single-stranded, three-stranded and four-stranded variations. Most in vitro p53-DNA affinity studies have been performed with short double-stranded oligonucleotides containing a p53 consensus sequence. DNA in the cell nucleus is not present in such a form: nuclear DNA is involved in long linear chromosomal structures and is organized on several levels. Thus, accessibility of genomic DNA is dependent on its organization and interaction with diverse proteins. It is an inherently complex process to pack long chromosomes into a structure that fits into the nucleus. Moreover, this structure must not be rigid but has to be flexible to allow functional roles of DNA. Therefore, DNA in the nucleus can be present as double-stranded DNA not only in the "standard" B-DNA conformation but also in different double-stranded variations such as A-DNA, C-DNA, and Z-DNA (Figure 1). Many studies have shown that p53 binds to damaged, mismatched, and/or distorted double-stranded DNA [66-68]. These p53 binding modes are crucial for p53 stabilization and trigger its posttranslational modification and accumulation, leading to its sequence-specific binding. From this point of view, DNA distortions and/or transitions between various double-stranded DNA conformations may be involved in rapid p53 activation for sequence-specific DNA binding (particularly when sites of structural variation are located in close proximity to the p53 sequence-specific motif).
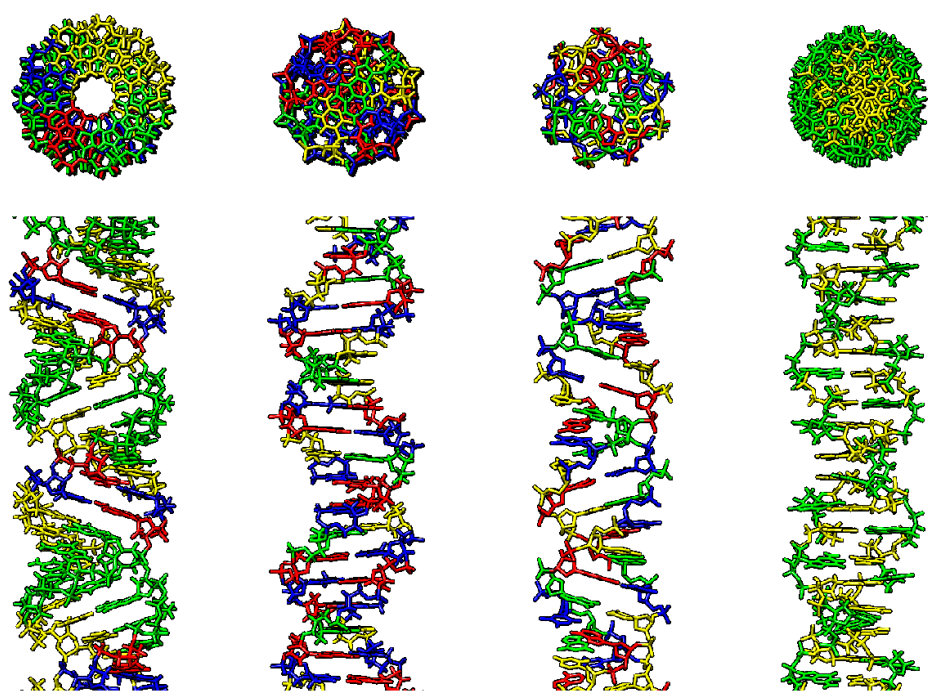

Figure 1. Various double-stranded DNA conformations, right-handed: A-DNA, B-DNA, C-DNA, left-handed: Z-DNA (from left to right). First row-upper view, second row-side view. A-DNA-AGGGGCCCCT repeat, B-DNA-random sequence, Z-DNA-CG repeat. Visualized using Chimera software, A-blue, C-yellow, G-green, T-red.

The p53 central domain is the major region responsible for sequence-specific binding to double-stranded B-DNA and this region contains all of the common, hotspot, mutations seen in cancer. These hotspot mutations either alter the conformation of the DNA binding domain (such as $\mathrm{R} 175 \mathrm{H}$ ) or involve mutation of an amino acid that directly contacts DNA (such as R273H), reducing or abolishing sequence-specific transactivation [69-71]. The crystal structure of the p53 core domain with a linear DNA target has shown the importance of individual amino acid residues interacting with DNA [72] and were verified several times [73-76]. It has been also demonstrated that DNA bending is important for p53 target sequence recognition [77]. Due to the lack of data for full-length p53 protein interactions with non-B DNAs, we used PDB data of p53 structure (combined with de novo predictions of particular unresolved regions by i-TASSER [78]) and Z-DNA, Triplex and G-quadruplex DNA PDBs to predict p53 interactions with these structures in silico by HDOCK tool [79]. The results 
of these analyses were visualized in UCSF Chimera software [80] and are shown in Figure 2. Various parts of the protein are predicted to interact with various DNA structures. While Z-DNA interacts with p53 mainly at residues in the central part (Figure 2A), triplex (Figure 2B) and G-quadruplex (Figure 2C) interacting residues are located mainly in the C-terminal domain, which corresponds to the experimental observations discussed below.
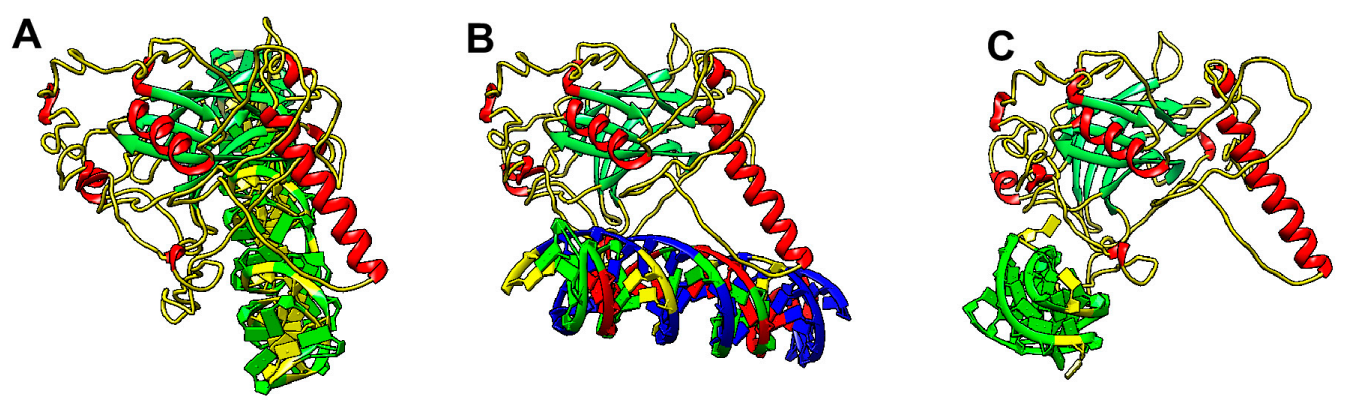

Figure 2. In silico model of human p53 interactions with Z-DNA (A), Triplex DNA (B) and G-quadruplex DNA (C). Visualized using Chimera software, Protein: helices-red, beta-sheets-green, DNA: A-blue, C-yellow, G-green, T-red.

\section{3. p53 Binding to DNA Structures Presented in Single-, Triple- and Four-Stranded DNA Motifs}

Besides the variations in double-stranded DNA structures, important regulatory roles have been ascribed to secondary DNA structures consisting of different numbers of chains and/or involving single-stranded parts. The classic example of secondary structure in nucleic acids is the presentation of RNAs as folded single-stranded molecules forming various functional three-dimensional structures with or without protein parts, such as tRNAs, ribosomal RNAs, SRP RNA, snRNA, snoRNA, lncRNA, etc. However, several alternative DNA structures have been characterized in vitro and their existence has recently been demonstrated in vivo. Considering that the preferential binding of p53 to single-stranded DNA was shown more than thirty years ago [81,82], it is perhaps not surprising that p53 binding to several local DNA structures present as non-B (or more generally non-double-stranded) DNA was described. The overview of various local DNA structures with different numbers of DNA strands is shown in Figure 3.

A

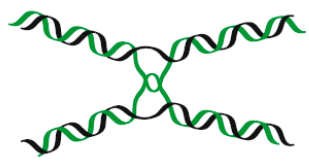

C

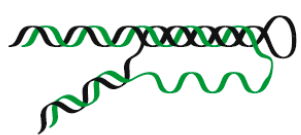

E

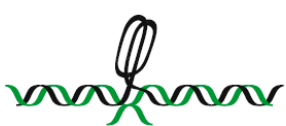

B

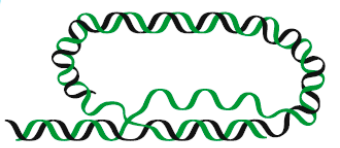

D

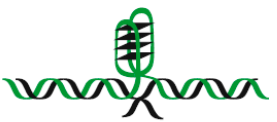

$\mathbf{F}$

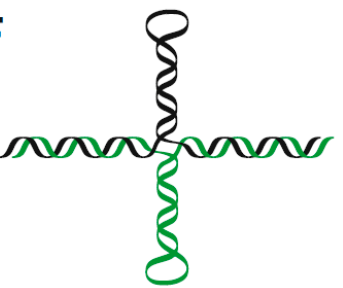

Figure 3. DNA structures with various numbers of strands (A) hemicatenate DNA (single- and four-stranded parts), (B) T-loop (single-, four-stranded part with DNA junction) (C) Triplex DNA (singleand three-stranded DNA), (D) G-quadruplex (four-stranded) (E) I-motif (four-stranded) (F) Cruciform with loops (single-, double- and four-stranded junction). Parts B, C, D, and F are adapted from [83]. 
Besides the recent ChIP-seq results showing that a remarkable number of precipitated DNAs do not contain the $\mathrm{p} 53$ consensus sequence, results showing preferential binding of wild-type p53 to supercoiled DNA (both containing and lacking the consensus sequence) pointed to p53 structure-specific DNA binding [84-87]. Selective binding to supercoiled DNA was later demonstrated for mutant p53 (tested for seven hot spot mutant p53 proteins (R175H, G245S, R248W, R249S, R273C, R273H and R282W), while the same plasmid DNAs in linear or relaxed circular forms were poorly bound in the absence of a consensus sequence [88]. This preference for supercoiled DNA has also been confirmed in cells using ChIP. These studies were initially performed on a circular plasmid with negative supercoiled DNA and later also for positively supercoiled DNA $[89,90]$. Experiments with superhelical DNA topoisomers revealed that p53 prefers DNA molecules with higher numbers of super turns [90-92]. Notably, negative DNA superhelicity is known to stabilize different non-B DNA structures. An increasing number of papers are demonstrating the regulatory importance of these local DNA structures in the human genome [93-95] and, for example, G-quadruplexes have been suggested as promising targets in cancer treatment $[44,45,96]$. Interestingly, inhibition of topoisomerases, resulting in accumulation of DNA superhelicity, leads to changes in p53-directed regulations in human cell lines [97]. Considering the stabilizing effects of negative superhelicity on local DNA structures including cruciforms, triplexes, and quadruplexes [33,98], it seems that local DNA structure protrusions also play a role in the mechanisms behind p53 function. Indeed, p53 preferential interactions with various local DNA structures have been shown: p53 is able to bind to mismatched DNA duplexes [67], three-way or four-way junctions [99,100], telomere T-loops [101], hemicatenated DNA [102], DNA loops [43], cruciforms [103-106], triplexes [37], and quadruplexes [107,108].

\subsubsection{Hemicatenate DNA}

Hemicatenates (Figure 3A) are essential intermediates of DNA replication, repair, and recombination [109]. These structures consist of distorted double helical, single-stranded and four-stranded motifs. Based on their length and base content, they can adopt various 3D structures, however, their basic characteristic-distortion of the B-DNA structure and shorter or longer single-stranded DNA chains-is typical for hemicatenanes. The presence of hemicatenate DNA can lead to DNA fragmentation and it is crucial to remove it before replication. Therefore, hemicatenanes are resolved by topoisomerases, and topoisomerase inhibition leads to increased strand breakage in DNA $[110,111]$. It has been demonstrated that p53 binds hemicatenate DNA in vitro by gel-shift assays [102,112]. Interestingly, not only one type of complex is formed by the interaction of p53 with hemicatenate DNA, but three different complexes can be formed, indicating that p53 can recognize both single-stranded loops present in the hemicatenate DNA and the central part of the structure which is multi-stranded. Whilst the p53 C-terminal domain has been proposed to play an important role in binding to supercoiled DNA, C-terminally deleted p53 still selectively interacts with hemicatenate DNA [102].

\subsubsection{Telomeric T-Loops}

In contrast to circular genomes found in the majority of bacteria as well as mitochondria and plastids, the ends of linear chromosomal DNA form specific protective structures. For mammalian telomere formation, so-called T-loops are typical [113,114]. This T-loop structure (Figure 3B) is formed by a $3^{\prime}$ single-stranded overhang of at least one TTAGGG repeat, Holliday junction-like structure, distorted double-stranded DNA and C-rich and G-rich parts that are prone to form non-B DNA structures [115]. The p53 binding preference to Holliday junctions was shown more than twenty years ago [99]. Therefore, p53 binding to T-loops is not surprising and p53 interacts with T-loop structures as a tetramer or as two tetramers [101]. Furthermore, p53 binds single-stranded TTAGGG with high affinity in oligonucleotides as well as in the presumably double-stranded form in plasmid DNA [101]. Moreover, the strand transfer activity of p53 may involve the formation of T-loops and cooperatively support TRF-2-mediated formation of the T-loop structure in vivo [115]. Both of these 
proteins have been detected together at the T-loop junction, suggesting the importance of p53 in T-loop formation and/or maintenance [101]. On the other hand, direct interactions of p53 with T-loop DNA have not been proven in vivo and it seems that DNA damage at human telomeres is prevented by p53 indirectly $[116,117]$.

\subsubsection{Three-Stranded Structure}

Repetitive sequences with mirror symmetry, consisting of homopurine homopyrimidine tracks, are capable of forming so-called triplex structures (Figure 3C), involving a segment of DNA with three nucleic acid strands. The third strand is typically bound by Hoogsteen pairing in the deep groove of the double-stranded DNA. Intramolecular triplexes are formed via the refolding of a segment of duplex DNA, which results in leaving a part of the DNA single-stranded. The formation of a triplex structure leads to torsions in surrounding parts of the DNA molecule [118]. Intermolecular triplexes with either third DNA or RNA strands have been described [119]. Triplex-forming sequences occur non-randomly in the human genome and have been found by bioinformatic approaches in several gene promoters, for example the IL2R, POLA1, and MYC genes [120], implying that triplex structures are involved in transcriptional regulation. In this regard, it has been demonstrated recently that formation of RNA-DNA triplexes leads to transcriptional inhibition in human cell lines. Formation of these RNA-DNA triplexes by interactions of long non-coding RNA with DNA could, therefore, be involved in additional or alternative transcription regulatory mechanisms. p53 binding to a plasmid DNA with confirmed presence of a triplex structure shows an increased affinity in comparison with supercoiled DNA without the triplex-forming DNA sequence [37]. Interestingly, this preferential binding to triplex-containing DNA was reduced by pre-treatment with monoclonal antibodies that bind to and block the C-terminal domain of p53. This result is in agreement with the in silico model of p53-triplex interaction (Figure 3B). Compared to p53 binding to hemicatenate DNA, it seems that the C-terminal domain of p53 plays a crucial role in triplex recognition. On the other hand, in vitro ELISA showed that both the core and the C-terminal p53 domains are capable of binding TAT triplex. Thus, cooperation of these two domains of p53 seems to be important for recognition of triplex structures [37]. Very interesting results were shown by luciferase reporter assays and RT-PCR: while an isolated triplex structure in a plasmid introduced into a human cell line showed no influence on transactivation by p53, significant enhancement of p53 dependent transactivation was detected when the same triplex-forming sequence was present next to the p53 consensus target sequence [37].

\subsubsection{Four-Stranded Structures}

G/C-rich nucleic acid sequences are prone to form two types of quadruplex structures: G-quadruplexes (Figure 3D) formed by G tetrads, or i-motifs (Figure 3E) formed by two intertwisted C-loops [121,122]. To date, the majority of research has been focused on G-quadruplexes, which can form thermodynamically more stable structures in physiological conditions compared to double-stranded B-DNA with the same sequence [123,124]. The arrangement of G-quadruplexes varies depending on the G-track repetition length, number and kind of bases interrupting the G-tracks, ionic conditions, etc., as reported in several studies $[30,125,126]$. Nevertheless, the principal structural features are common for all G-quadruplexes: the arrangement of guanine quartets stabilized by Hoogsteen hydrogen interaction, the presence of a (usually) monovalent ion (optimally $\mathrm{K}^{+}$) in the middle of the G-quad bucket, single-stranded loops at the top and bottom parts of the structure and a four-way junction where the G-quadruplex structure is attached to the double-stranded DNA. Current research has emphasized the significance of G-quadruplexes in numerous cellular processes such as DNA replication, telomere maintenance and the binding and activity of transcription factors [127-129]. Hot-spot mutant p53 proteins bind weakly or do not bind to p53 target sequences $[2,130]$ and these weak p53-DNA interactions are insufficient for effective transcription activation [131-134]. On the other hand, both wild type and mutant p53 (R273H) are able to bind G-quadruplexes. The C-terminal domain is therefore suggested as more important for G-quadruplex DNA binding compared to the 
central p53 domain, which is in agreement with the in silico model of p53-G-quadruplex interaction (Figure 3C). Interestingly, p53-DNA binding affects transcription from G-rich regulatory regions [135]. Mutant p53 proteins are known to modify transcription levels via their interactions with intronic and intergenic sequences predisposed to form non-B DNA structures [136]. Enrichment of mutant p53 $(\mathrm{R} 273 \mathrm{H})$ bound to regions from $1 \mathrm{~kb}$ upstream to $1 \mathrm{~kb}$ downstream of TSSs overlaps with CpG islands and about $75 \%$ of mutant p53 binding regions are predicted to contain G-quadruplex motifs [135]. This suggests the ability of p53 to recognize quadruplex DNA structures in vivo. It was also shown that p53 stabilizes G-quadruplex structures, but the p53 interaction with the G-quadruplex could be also mediated by interaction with other G-quadruplex recognizing transcription factors, such as ETS1, SP1 and others [137-139]. p53 interacts with the G-quadruplex-forming sequence present in the MYC promoter and represses transcription in vitro and in human cell lines [107]. Interestingly, some quadruplex-stabilizing ligands, such as $N$-methyl mesoporphyrin IX, boost the interaction of p53 to the G-quadruplex formed by the human telomeric repeat sequence [108].

\subsubsection{Loops and Cruciforms}

The presence of various repetitive sequences is typical for the genomes of all organisms. Many trinucleotide repeats have been described in the human genome, and their expansion is associated with neurological, degenerative and muscular diseases such as Friedreich's Ataxia and Huntington's disease $[42,140,141]$. Genomic elements with trinucleotide repeats are very flexible and are able to form non-B DNA structures such as loops, hairpins, triplexes and slipped-strand structures [142,143]. An important regulatory role has been ascribed also to inverted repeats. Such palindromic sequences are often identified as protein targets $[103,144,145]$. They are prone to form cruciform structures, which consist of a branch point (represented by a four-way junction), a stem (double-stranded) and a loop (single-stranded). Depending on the length and on whether the inverted repeat is direct or separated by a spacer, cruciforms with shorter or longer single-stranded loops are formed (Figure 4).

Inverted repeats are present non-randomly in the genome and are often located in the proximity of breakpoint junctions, promoters, and replication origins $[57,144,146]$. Interestingly, many p53 target sequences in double-stranded DNA with a high transactivation activity in vivo contain inverted repeats $[2,85,106]$ and there is a correlation between the presence of an inverted repeat in the p53 target site and enhancement of p53-DNA binding [92,147]. The formation of cruciforms within p53 double-stranded target sites facilitates p53-DNA binding in topologically constrained DNA [85]. A correlation between inverted repeat presence in the CDKN1A gene promoter and effective p53 binding was demonstrated by ChIP $[104,148]$. Analyses of genome-wide p53 ChIP data after cellular stress showed that the majority of sequences contain at least part of the p53 consensus sequence $(93 \%)$ and 2245 of 2250 (99\%) sequences contain at least one inverted repeat [52]. Moreover, inverted repeats are often present in close proximity (within $20 \mathrm{bp}$ ) of p53 target sequences (76\% of p53-ChIPed sequences) and $34 \%$ contained the inverted repeat directly within the $20 \mathrm{bp}$ long p53 consensus sequence (Figure 5). ChIP and yeast transactivation assays have demonstrated the preferential binding of p53 to cruciform-forming inverted repeats within p53 target sequences $[104,106]$. Most probably, better accessibility and stability of the protein-DNA complex leads to the improved p53 function at the fully symmetrical p53 target sites. An enhancement effect of a DNA loop in close proximity to a p53 B-DNA target has also been shown for triplex DNA [37] and for DNA loops formed by triplex expansion associated with Friedreich's ataxia [43]. The presence of single-stranded loops and/or four-way junctions in a cruciform could contribute to the p53-DNA binding at cruciform-forming target sequences. Interestingly, p53 interaction with Holliday junctions (another four-way junction motif occurring in DNA) has been reported [99] and it was suggested that p53 plays an important role in protecting this structure against endonuclease cleavage. The $\mathrm{p} 53$ protein has been described to exhibit a binding preference to cruciforms even in the absence of a target sequence, demonstrated using various techniques including direct visualization by atomic force microscopy $[149,150]$. The correlation between negative DNA supercoiling (facilitating local transitions from B-form DNA into a cruciform at 
the inverted repeats) and p53 binding enhancement suggests the importance of spatial DNA assembly for effective p53 binding [2,92].

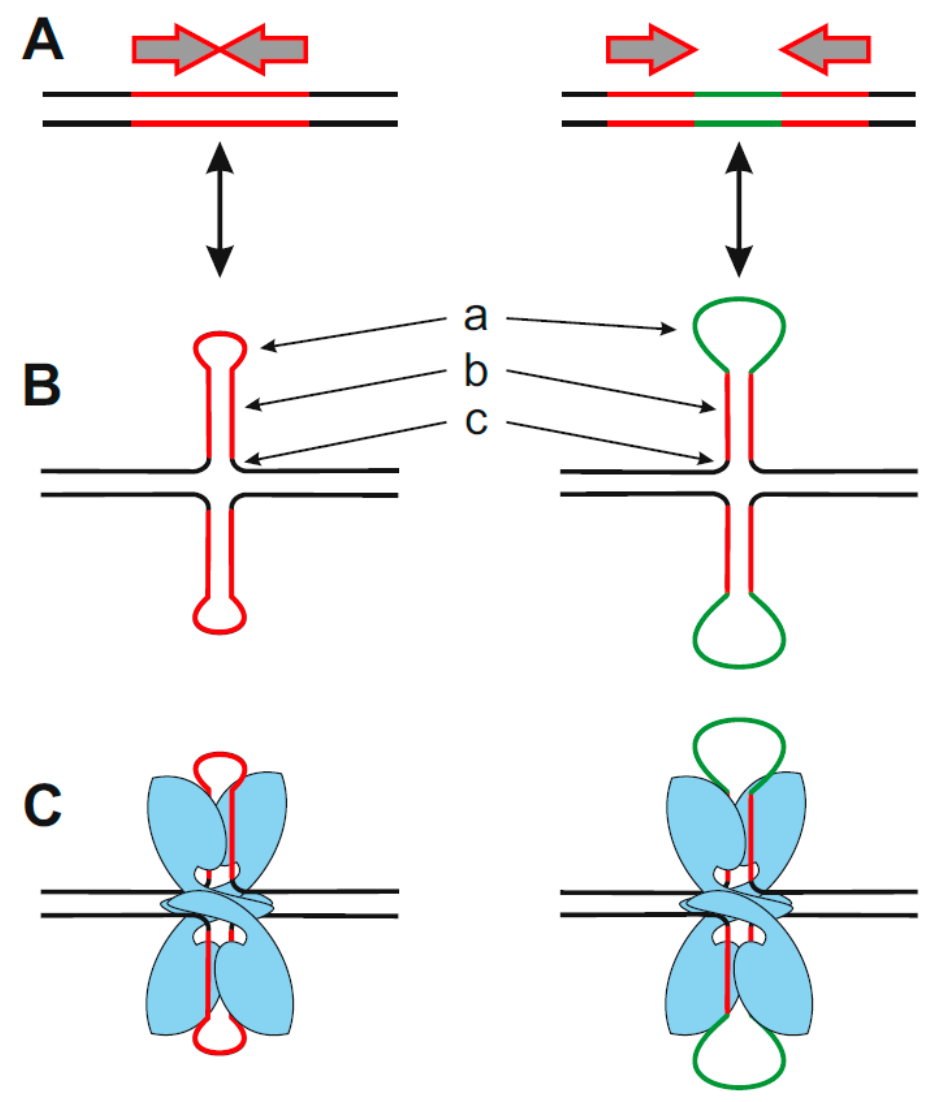

Figure 4. Cruciform structure formation (A) inverted repeat (red) without spacer (left part) or with spacer (green-right part) is required for (B) cruciform structure formation, the length of the repeat and spacer influence the length of the single-stranded loop (a), size of the stem (b). Every cruciform consist of four-way junction (c). Two p53 half-sites formed by inverted repeats could be close in cruciform structure allowing effective binding of p53 (blue) (C).

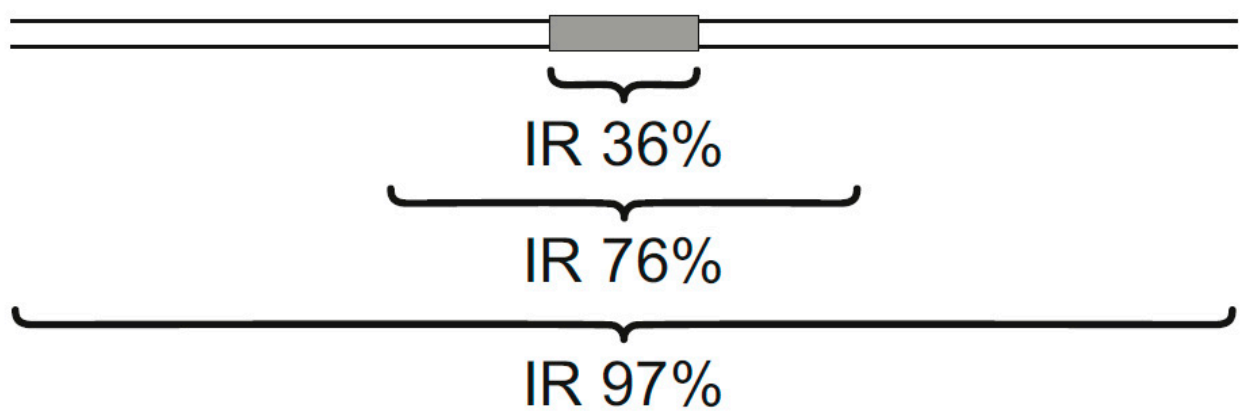

Figure 5. Frequencies and localization of inverted repeats in p53-ChIPed fragments, within a p53 double-stranded target, 20-bp around and 100-bp around.

\subsubsection{Influence of Epigenetic Changes to p53-DNA Interactions}

It is well-known that many basic biological processes including gene expression depend on chromatin epigenetic states, such as DNA methylation [151] and histone modifications [152], and on noncoding RNA-mediated regulation [153]. Changes in these epigenetic features are seen in neurological diseases and cancer and become important in clinical medicine [154]. These epigenetic phenomena are important for p53-DNA binding as well for local DNA structure formation. p53 
targets are typically associated with histone marks of transcriptionally active chromatin (H3K4me3 and H3K36me3) in normal cells and cancer cell lines typically have lower levels of DNA methylation [155]. It was experimentally validated that methylation changes alter p53 regulation [156]. Examination of genome-wide data sets shows three classes of p53 targets-near transcriptional start sites (TSS), promoter-distal enhancer elements with dynamic histone acetylation upon p53 binding, and within regions of inaccessible chromatin [157]. These data point to p53 acting as a pioneer transcription factor [158], similarly to the FoxA transcription factor [159]. The presence of local DNA structures are associated with an active genome when transcription and replications lead to increased superhelicity favor local DNA structure formation and dynamic changes in DNA supercoiling in vivo determine DNA accessibility for transcription [34]. These changes of superhelicity lead to cruciform extrusion [160]. The positive effect of p53 binding to supercoiled DNA has been demonstrated $[85,86]$ and DNA supercoiling changes transcription in general [161,162]. Interestingly, loss of histone modifications (H3K4me3 and H3K9/14ac) around the TSS correlates with G-quadruplex prone sequences [163]. G-quadruplex ligands change epigenetic modification and, therefore, targeting of local DNA structures was suggested as a tool for specific epigenetic reprogramming [164]. Considering that cruciform structures as well for G-quadruplex have been shown to protect DNA from methylation $[165,166]$, formation of local DNA structures could be an important additional factor in the p53 pioneering and DNA binding activities.

\section{Conclusions}

p53 binding to DNA is a basic feature important for its transcriptional-regulation function. In dependence of chromatin state, p53 shows the ability to bind to its target sequences in double-stranded DNA (reviewed in [2,46-52]) and/or to local non-B DNA structures [83] that may or may not be associated with a p53 consensus target sequence (Figure 6).

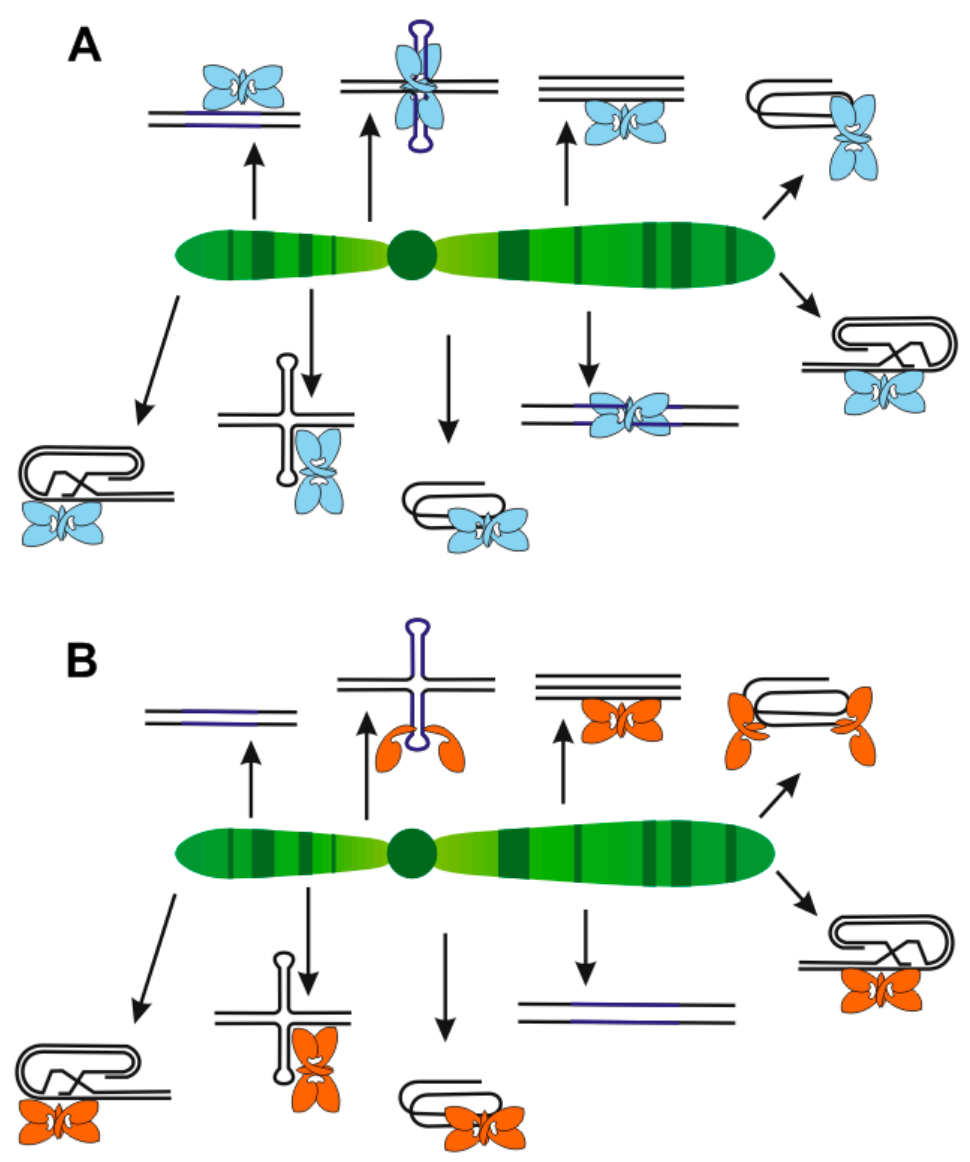

Figure 6. Various targets for wild-type (A-blue) and mutant (B-violet) proteins. 
These local DNA structures represent a variety of DNA targets also as single-, three-, and four-stranded DNA. Interestingly, simultaneous binding of p53 to sequence- and structure-specific motifs shows remarkable cooperativity, evidenced by the proximity effects of triplex DNA located close to p53 double-stranded target DNA [37] and by the structural transition of symmetrical consensus target sequences from double-stranded B-DNA into corresponding cruciform structures [104] (Figure 4). These synergistic effects are observed not only at the level of increased protein-DNA binding affinity but also at the level of enhanced transcriptional activity. Some other local DNA structures, such as G-quadruplexes, have been identified as targets for mutant p53 proteins, which have lost sequence-specific DNA binding. In general, the C-terminal part of p53 is required for its effective structure-selective DNA binding. Moreover, tetrameric p53 binds DNA in a cooperative manner and activation of the apoptosis program is dependent on DNA binding cooperativity, while p53 mutants with reduced or increased cooperativity change the cell fate $[167,168]$. Mutant p53 with "gain of function" properties, which can be related to the mutant protein binding to certain structural motifs such as G-quadruplexes, plays a critical role in human tumor progression. It has been demonstrated that functional loss of p53 influences cell microenvironments and promotes malignant progression [169]. Mutant p53 also promotes invasiveness of cancer cells by extensive gene upregulation, for example, murine mutant $\mathrm{p} 53 \mathrm{R} 270 \mathrm{H}$ (the equivalent of human $\mathrm{R} 273 \mathrm{H}$ ) is associated with activation of inflammatory and innate immune pathways [170]. It was also demonstrated that dominant-negative and "gain of function" features of mutant p53 could be reduced by allele-specific siRNAs against p53 hotspot mutants [171]. While mutant p53 imbalanced p53-DNA binding equilibrium, targeted degradation of mutant $\mathrm{p} 53$ seems to be a promising strategy for treatment [172]. Moreover, the role of p53 isoforms has emerged in recent years [70,173,174]. Due to the altered C-terminal parts of $\mathrm{p} 53 \beta$ and $\mathrm{p} 53 \gamma$ isoforms, their DNA binding specificity to local DNA structures can be very different in comparison to the canonical p53 $\alpha$ isoform. The evaluation of individual p53 mutants and p53 isoforms interacting with local DNA structures will shed light on the complex regulatory pathways controlled through orchestration of processes involving the p53 protein.

Author Contributions: Both authors contributed to this review. V.B. conceived the idea, prepared the text and Figures 2-6. M.F. prepared and revised the text. Both authors read and approved the final manuscript.

Funding: This work was supported by The Czech Science Foundation (18-15548S) and by the SYMBIT project Reg. no. CZ.02.1.01/0.0/0.0/15_003/0000477 financed from the ERDF.

Acknowledgments: We thank Martin Bartas for preparation of Figures 1 and 2, Jana Vachová for final Figures editing and Philip J. Coates for proofreading and editing the manuscript.

Conflicts of Interest: The authors declare no conflict of interest.

\section{References}

1. Vousden, K.H.; Lane, D.P. p53 in health and disease. Nat. Rev. Mol. Cell Biol. 2007, 8, 275-283. [CrossRef] [PubMed]

2. Gohler, T.; Reimann, M.; Cherny, D.; Walter, K.; Warnecke, G.; Kim, E.; Deppert, W. Specific interaction of p53 with target binding sites is determined by DNA conformation and is regulated by the C-terminal domain. J. Biol. Chem. 2002, 277, 41192-41203. [CrossRef] [PubMed]

3. Meek, D.W. Regulation of the p53 response and its relationship to cancer. Biochem. J. 2015, 469, 325-346. [CrossRef] [PubMed]

4. Kaiser, H.E.; Bodey, B. The role of apoptosis in normal ontogenesis and solid human neoplasms. In Vivo 2000, 14, 789-803. [PubMed]

5. Kylarová, D.; Vrchovecký, J.; Holinka, M.; Erdösová, B. The occurrence of c-myc, p53 and Bcl-2 family proteins in the early phase of development of duodenal epithelium. Biomed. Pap. Med. Fac. Univ. Palacky Olomouc Czech Repub. 2004, 148, 229-232. [CrossRef] [PubMed]

6. Prochazkova, J.; Lichnovsky, V.; Kylarova, D.; Erdosova, B.; Vranka, P. Involvement of p53 and Bcl-2 family proteins in regulating programmed cell death and proliferation in human embryogenesis. Gen. Physiol. Biophys. 2004, 23, 209-229. 
7. Porrello, A.; Cerone, M.A.; Coen, S.; Gurtner, A.; Fontemaggi, G.; Cimino, L.; Piaggio, G.; Sacchi, A.; Soddu, S. P53 Regulates Myogenesis by Triggering the Differentiation Activity of pRb. J. Cell Biol. 2000, 151, 1295-1304. [CrossRef]

8. Vousden, K.H.; Ryan, K.M. p53 and metabolism. Nat. Rev. Cancer 2009, 9, 691-700. [CrossRef]

9. Chen, J. The Cell-Cycle Arrest and Apoptotic Functions of p53 in Tumor Initiation and Progression. Cold Spring Harb. Perspect. Med. 2016, 6, a026104. [CrossRef]

10. Kaiser, A.M.; Attardi, L.D. Deconstructing networks of p53-mediated tumor suppression in vivo. Cell Death Differ. 2018, 25, 93-103. [CrossRef]

11. Wang, X.; Simpson, E.R.; Brown, K.A. p53: Protection against Tumor Growth beyond Effects on Cell Cycle and Apoptosis. Cancer Res. 2015, 75, 5001-5007. [CrossRef] [PubMed]

12. Ranjan, A.; Iwakuma, T. Non-Canonical Cell Death Induced by p53. Int. J. Mol. Sci. 2016, 17, 2068. [CrossRef] [PubMed]

13. Pfaff, M.J.; Mukhopadhyay, S.; Hoofnagle, M.; Chabasse, C.; Sarkar, R. Tumor suppressor protein p53 negatively regulates ischemia-induced angiogenesis and arteriogenesis. J. Vasc. Surg. 2018, 68, 222S-233S.e1. [CrossRef] [PubMed]

14. Chandrangsu, S.; Sappayatosok, K. p53, p63 and p73 expression and angiogenesis in keratocystic odontogenic tumors. J. Clin. Exp. Dent. 2016, 8, e505-e511. [CrossRef] [PubMed]

15. Williams, A.B.; Schumacher, B. p53 in the DNA-Damage-Repair Process. Cold Spring Harb. Perspect. Med. 2016, 6, a026070. [CrossRef] [PubMed]

16. Nicolai, S.; Rossi, A.; Di Daniele, N.; Melino, G.; Annicchiarico-Petruzzelli, M.; Raschellà, G. DNA repair and aging: The impact of the p53 family. Aging 2015, 7, 1050-1065. [CrossRef]

17. Rufini, A.; Tucci, P.; Celardo, I.; Melino, G. Senescence and aging: The critical roles of p53. Oncogene 2013. [CrossRef]

18. Hussain, M.; Tian, K.; Mutti, L.; Krstic-Demonacos, M.; Schwartz, J.-M. The Expanded p53 Interactome as a Predictive Model for Cancer Therapy. Genom. Comput. Biol. 2015, 1, e20. [CrossRef]

19. Muller, P.A.J.; Vousden, K.H. p53 mutations in cancer. Nat. Cell Biol. 2013, 15, 2-8. [CrossRef]

20. Valenti, F.; Fausti, F.; Biagioni, F.; Shay, T.; Fontemaggi, G.; Domany, E.; Yaffe, M.B.; Strano, S.; Blandino, G.; Di Agostino, S. Mutant p53 oncogenic functions are sustained by Plk2 kinase through an autoregulatory feedback loop. Cell Cycle 2011, 10, 4330-4340. [CrossRef]

21. Liu, K.; Ling, S.; Lin, W.-C. TopBP1 mediates mutant p53 gain of function through NF-Y and p63/p73. Mol. Cell. Biol. 2011, 31, 4464-4481. [CrossRef] [PubMed]

22. Stindt, M.H.; Muller, P.A.J.; Ludwig, R.L.; Kehrloesser, S.; Dötsch, V.; Vousden, K.H. Functional interplay between MDM2, p63/p73 and mutant p53. Oncogene 2015, 34, 4300-4310. [CrossRef] [PubMed]

23. Inoue, K.; Fry, E.A.; Frazier, D.P. Transcription factors that interact with p53 and Mdm2. Int. J. Cancer 2016, 138, 1577-1585. [CrossRef] [PubMed]

24. Woods, Y.L.; Lane, D.P. Exploiting the p53 pathway for cancer diagnosis and therapy. Hematol. J. 2003, 4, 233-247. [CrossRef] [PubMed]

25. Cheok, C.F.; Lane, D.P. Exploiting the p53 Pathway for Therapy. Cold Spring Harb. Perspect. Med. 2017, 7, a026310. [CrossRef] [PubMed]

26. Levine, A.J.; Oren, M. The first 30 years of p53: Growing ever more complex. Nat. Rev. Cancer 2009, 9, 749-758. [CrossRef]

27. Lohrum, M.A.E.; Vousden, K.H. Regulation and activation of p53 and its family members. Cell Death Differ. 1999, 6, 1162-1168. [CrossRef]

28. Zhao, Y.; Chen, X.; Du, J. Cellular adaptation to hypoxia and p53 transcription regulation. J. Zhejiang Univ.-Sci. B 2009, 10, 404-410. [CrossRef]

29. Itoh, Y.; Murata, A.; Sakamoto, S.; Nanatani, K.; Wada, T.; Takahashi, S.; Kamagata, K. Activation of p53 Facilitates the Target Search in DNA by Enhancing the Target Recognition Probability. J. Mol. Biol. 2016, 428, 2916-2930. [CrossRef]

30. Bochman, M.L.; Paeschke, K.; Zakian, V.A. DNA secondary structures: Stability and function of G-quadruplex structures. Nat. Rev. Genet. 2012, 13, 770-780. [CrossRef]

31. Timsit, Y. DNA Self-Assembly: From Chirality to Evolution. Int. J. Mol. Sci. 2013, 14, 8252-8270. [CrossRef] [PubMed] 
32. Frees, S.; Menendez, C.; Crum, M.; Bagga, P.S. QGRS-Conserve: A computational method for discovering evolutionarily conserved G-quadruplex motifs. Hum. Genom. 2014, 8, 8. [CrossRef] [PubMed]

33. Palecek, E. Local supercoil-stabilized DNA structures. Crit. Rev. Biochem. Mol. Biol. 1991, 26, 151-226. [CrossRef] [PubMed]

34. Travers, A.; Muskhelishvili, G. DNA structure and function. FEBS J. 2015, 282, 2279-2295. [CrossRef]

35. Yahyaoui, W.; Callejo, M.; Price, G.B.; Zannis-Hadjopoulos, M. Deletion of the cruciform binding domain in CBP/14-3-3 displays reduced origin binding and initiation of DNA replication in budding yeast. BMC Mol. Biol. 2007, 8, 27. [CrossRef] [PubMed]

36. Bedrat, A.; Lacroix, L.; Mergny, J.-L. Re-evaluation of G-quadruplex propensity with G4Hunter. Nucleic Acids Res. 2016, 44, 1746-1759. [CrossRef]

37. Brazdova, M.; Tichy, V.; Helma, R.; Bazantova, P.; Polaskova, A.; Krejci, A.; Petr, M.; Navratilova, L.; Ticha, O.; Nejedly, K.; et al. p53 Specifically Binds Triplex DNA In Vitro and in Cells. PLoS ONE 2016, 11, e0167439. [CrossRef]

38. Waller, Z.A.; Pinchbeck, B.J.; Buguth, B.S.; Meadows, T.G.; Richardson, D.J.; Gates, A.J. Control of bacterial nitrate assimilation by stabilization of G-quadruplex DNA. Chem. Commun. 2016, 52, 13511-13514. [CrossRef]

39. Bartas, M.; Čutová, M.; Brázda, V.; Kaura, P.; Št'astnỳ, J.; Kolomazník, J.; Coufal, J.; Goswami, P.; Červeň, J.; Pečinka, P. The Presence and Localization of G-Quadruplex Forming Sequences in the Domain of Bacteria. Molecules 2019, 24, 1711. [CrossRef]

40. Huppert, J.L.; Balasubramanian, S. G-quadruplexes in promoters throughout the human genome. Nucleic Acids Res. 2006, 35, 406-413. [CrossRef]

41. Siddiqui-Jain, A.; Grand, C.L.; Bearss, D.J.; Hurley, L.H. Direct evidence for a G-quadruplex in a promoter region and its targeting with a small molecule to repress c-MYC transcription. Proc. Natl. Acad. Sci. USA 2002, 99, 11593-11598. [CrossRef] [PubMed]

42. Rajeswari, M.R. DNA triplex structures in neurodegenerative disorder, Friedreich's ataxia. J. Biosci. 2012, 37, 519-532. [CrossRef] [PubMed]

43. Helma, R.; Bažantová, P.; Petr, M.; Adámik, M.; Renčiuk, D.; Tichý, V.; Pastuchová, A.; Soldánová, Z.; Pečinka, P.; Bowater, R.P.; et al. p53 Binds Preferentially to Non-B DNA Structures Formed by the Pyrimidine-Rich Strands of GAA.TTC Trinucleotide Repeats Associated with Friedreich's Ataxia. Molecules 2019, 24, 2078. [CrossRef] [PubMed]

44. Cimino-Reale, G.; Zaffaroni, N.; Folini, M. Emerging Role of G-quadruplex DNA as Target in Anticancer Therapy. Curr. Pharm. Des. 2016, 22, 6612-6624. [CrossRef]

45. Asamitsu, S.; Obata, S.; Yu, Z.; Bando, T.; Sugiyama, H. Recent Progress of Targeted G-Quadruplex-Preferred Ligands Toward Cancer Therapy. Molecules 2019, 24, 429. [CrossRef] [PubMed]

46. Ma, B.; Pan, Y.; Zheng, J.; Levine, A.J.; Nussinov, R. Sequence analysis of p53 response-elements suggests multiple binding modes of the 53 tetramer to DNA targets. Nucleic Acids Res. 2007, 35, 2986-3001. [CrossRef] [PubMed]

47. Wei, C.L.; Wu, Q.; Vega, V.B.; Chiu, K.P.; Ng, P.; Zhang, T.; Shahab, A.; Yong, H.C.; Fu, Y.T.; Weng, Z.P.; et al. A global map of p53 transcription-factor binding sites in the human genome. Cell 2006, 124, 207-219. [CrossRef]

48. Menendez, D.; Inga, A.; Resnick, M.A. The expanding universe of p53 targets. Nat. Rev. Cancer 2009, 9, 724-737. [CrossRef]

49. Menendez, D.; Inga, A.; Resnick, M.A. Potentiating the p53 network. Discov. Med. 2010, 10, 94-100.

50. Wang, B.; Xiao, Z.; Ren, E.C. Redefining the p53 response element. Proc. Natl. Acad. Sci. USA 2009, 106, 14373-14378. [CrossRef]

51. Allen, M.A.; Andrysik, Z.; Dengler, V.L.; Mellert, H.S.; Guarnieri, A.; Freeman, J.A.; Sullivan, K.D.; Galbraith, M.D.; Luo, X.; Kraus, W.L.; et al. Global analysis of p53-regulated transcription identifies its direct targets and unexpected regulatory mechanisms. Elite 2014, 3, e02200.

52. Chang, G.S.; Chen, X.A.; Park, B.; Rhee, H.S.; Li, P.; Han, K.H.; Mishra, T.; Chan-Salis, K.Y.; Li, Y.; Hardison, R.C.; et al. A Comprehensive and High-Resolution Genome-wide Response of p53 to Stress. Cell Rep. 2014, 8, 513-526. [CrossRef] [PubMed]

53. Cai, B.-H.; Chao, C.-F.; Huang, H.-C.; Lee, H.-Y.; Kannagi, R.; Chen, J.-Y. Roles of p53 Family Structure and Function in Non-Canonical Response Element Binding and Activation. Int. J. Mol. Sci. 2019, 20, 3681. [CrossRef] [PubMed] 
54. El-Deiry, W.S.; Kern, S.E.; Pietenpol, J.A.; Kinzler, K.W.; Vogelstein, B. Definition of a consensus binding site for p53. Nat. Genet. 1992, 1, 45. [CrossRef]

55. Qian, H.; Wang, T.; Naumovski, L.; Lopez, C.D.; Brachmann, R.K. Groups of p53 target genes involved in specific p53 downstream effects cluster into different classes of DNA binding sites. Oncogene 2002, 21, 7901-7911. [CrossRef]

56. Veprintsev, D.B.; Fersht, A.R. Algorithm for prediction of tumour suppressor p53 affinity for binding sites in DNA. Nucleic Acids Res. 2008, 36, 1589-1598. [CrossRef]

57. Brazda, V.; Kolomaznik, J.; Lysek, J.; Haronikova, L.; Coufal, J.; Stastny, J. Palindrome analyser-A new web-based server for predicting and evaluating inverted repeats in nucleotide sequences. Biochem. Biophys. Res. Commun. 2016, 478, 1739-1745. [CrossRef]

58. McKinney, K.; Mattia, M.; Gottifredi, V.; Prives, C. p53 linear diffusion along DNA requires its C terminus. Mol. Cell 2004, 16, 413-424. [CrossRef]

59. Brazda, V.; Jagelska, E.B.; Fojta, M.; Palecek, E. Searching for target sequences by p53 protein is influenced by DNA length. Biochem. Biophys. Res. Commun. 2006, 341, 470-477. [CrossRef]

60. Itoh, Y.; Murata, A.; Takahashi, S.; Kamagata, K. Intrinsically disordered domain of tumor suppressor p53 facilitates target search by ultrafast transfer between different DNA strands. Nucleic Acids Res. 2018, 46, 7261-7269. [CrossRef]

61. Nguyen, T.-A.T.; Grimm, S.A.; Bushel, P.R.; Li, J.; Li, Y.; Bennett, B.D.; Lavender, C.A.; Ward, J.M.; Fargo, D.C.; Anderson, C.W.; et al. Revealing a human p53 universe. Nucleic Acids Res. 2018, 46, 8153-8167. [CrossRef] [PubMed]

62. Kent, W.J.; Sugnet, C.W.; Furey, T.S.; Roskin, K.M.; Pringle, T.H.; Zahler, A.M.; Haussler, D. The human genome browser at UCSC. Genome Res. 2002, 12, 996-1006. [CrossRef] [PubMed]

63. Raney, B.J.; Dreszer, T.R.; Barber, G.P.; Clawson, H.; Fujita, P.A.; Wang, T.; Nguyen, N.; Paten, B.; Zweig, A.S.; Karolchik, D.; et al. Track data hubs enable visualization of user-defined genome-wide annotations on the UCSC Genome Browser. Bioinformatics 2014, 30, 1003-1005. [CrossRef] [PubMed]

64. Tebaldi, T.; Zaccara, S.; Alessandrini, F.; Bisio, A.; Ciribilli, Y.; Inga, A. Whole-genome cartography of p53 response elements ranked on transactivation potential. BMC Genom. 2015, 16, 464. [CrossRef] [PubMed]

65. Bao, X.; Wu, H.; Zhu, X.; Guo, X.; Hutchins, A.P.; Luo, Z.; Song, H.; Chen, Y.; Lai, K.; Yin, M.; et al. The p53-induced lincRNA-p21 derails somatic cell reprogramming by sustaining H3K9me3 and CpG methylation at pluripotency gene promoters. Cell Res. 2015, 25, 80-92. [CrossRef] [PubMed]

66. Pivonkova, H.; Brazdova, M.; Kasparkova, J.; Brabec, V.; Fojta, M. Recognition of cisplatin-damaged DNA by p53 protein: Critical role of the p53 C-terminal domain. Biochem. Biophys. Res. Commun. 2006, 339, 477-484. [CrossRef]

67. Degtyareva, N.; Subramanian, D.; Griffith, J.D. Analysis of the binding of p53 to DNAs containing mismatched and bulged bases. J. Biol. Chem. 2001, 276, 8778-8784. [CrossRef]

68. Walter, K.; Warnecke, G.; Bowater, R.; Deppert, W.; Ella, K. Tumor suppressor p53 binds with high affinity to CTG center dot CAG trinucleotide repeats and induces topological alterations in mismatched duplexes. J. Biol. Chem. 2005, 280, 42497-42507. [CrossRef]

69. Joerger, A.C.; Fersht, A.R. The tumor suppressor p53: From structures to drug discovery. Cold Spring Harb. Perspect. Biol. 2010, 2, a000919. [CrossRef]

70. Bourdon, J.-C.; Fernandes, K.; Murray-Zmijewski, F.; Liu, G.; Diot, A.; Xirodimas, D.P.; Saville, M.K.; Lane, D.P. p53 isoforms can regulate p53 transcriptional activity. Genes Dev. 2005, 19, 2122-2137. [CrossRef]

71. Sabapathy, K.; Lane, D.P. Understanding p53 functions through p53 antibodies. J. Mol. Cell Biol. 2019, 11, 317-329. [CrossRef] [PubMed]

72. Cho, Y.; Gorina, S.; Jeffrey, P.D.; Pavletich, N.P. Crystal structure of a p53 tumor suppressor-DNA complex: Understanding tumorigenic mutations. Science 1994, 265, 346-355. [CrossRef] [PubMed]

73. Zhao, K.; Chai, X.; Johnston, K.; Clements, A.; Marmorstein, R. Crystal structure of the mouse p53 core DNA-binding domain at 2.7 A resolution. J. Biol. Chem. 2001, 276, 12120-12127. [CrossRef] [PubMed]

74. Joerger, A.C.; Allen, M.D.; Fersht, A.R. Crystal structure of a superstable mutant of human p53 core domain. Insights into the mechanism of rescuing oncogenic mutations. J. Biol. Chem. 2004, 279, 1291-1296. [CrossRef]

75. Suad, O.; Rozenberg, H.; Brosh, R.; Diskin-Posner, Y.; Kessler, N.; Shimon, L.J.W.; Frolow, F.; Liran, A.; Rotter, V.; Shakked, Z. Structural basis of restoring sequence-specific DNA binding and transactivation to mutant p53 by suppressor mutations. J. Mol. Biol. 2009, 385, 249-265. [CrossRef] 
76. Malecka, K.A.; Ho, W.C.; Marmorstein, R. Crystal structure of a p53 core tetramer bound to DNA. Oncogene 2009, 28, 325-333. [CrossRef]

77. Nagaich, A.K.; Appella, E.; Harrington, R.E. DNA bending is essential for the site-specific recognition of DNA response elements by the DNA binding domain of the tumor suppressor protein p53. J. Biol. Chem. 1997, 272, 14842-14849. [CrossRef]

78. Yang, J.; Yan, R.; Roy, A.; Xu, D.; Poisson, J.; Zhang, Y. The I-TASSER Suite: Protein structure and function prediction. Nat. Methods 2015, 12,7-8. [CrossRef]

79. Yan, Y.; Zhang, D.; Zhou, P.; Li, B.; Huang, S.-Y. HDOCK: A web server for protein-protein and protein-DNA/RNA docking based on a hybrid strategy. Nucleic Acids Res. 2017, 45, W365-W373. [CrossRef]

80. Pettersen, E.F.; Goddard, T.D.; Huang, C.C.; Couch, G.S.; Greenblatt, D.M.; Meng, E.C.; Ferrin, T.E. UCSF Chimera-A visualization system for exploratory research and analysis. J. Comput. Chem. 2004, 25, 1605-1612. [CrossRef]

81. Bakalkin, G.; Yakovleva, T.; Selivanova, G.; Magnusson, K.P.; Szekely, L.; Kiseleva, E.; Klein, G.; Terenius, L.; Wiman, K.G. p53 binds single-stranded DNA ends and catalyzes DNA renaturation and strand transfer. Proc. Natl. Acad. Sci. USA 1994, 91, 413-417. [CrossRef] [PubMed]

82. Bakalkin, G.; Selivanova, G.; Yakovleva, T.; Kiseleva, E.; Kashuba, E.; Magnusson, K.P.; Szekely, L.; Klein, G.; Terenius, L.; Wiman, K.G. p53 binds single-stranded DNA ends through the C-terminal domain and internal DNA segments via the middle domain. Nucleic Acids Res. 1995, 23, 362-369. [CrossRef] [PubMed]

83. Brázda, V.; Coufal, J. Recognition of local DNA structures by p53 protein. Int. J. Mol. Sci. 2017, 18, 375. [CrossRef] [PubMed]

84. Palecek, E.; Vlk, D.; Stankova, V.; Brazda, V.; Vojtesek, B.; Hupp, T.R.; Schaper, A.; Jovin, T.M. Tumor suppressor protein p53 binds preferentially to supercoiled DNA. Oncogene 1997, 15, 2201-2209. [CrossRef]

85. Palecek, E.; Brazda, V.; Jagelska, E.; Pecinka, P.; Karlovska, L.; Brazdova, M. Enhancement of p53 sequence-specific binding by DNA supercoiling. Oncogene 2004, 23, 2119-2127. [CrossRef]

86. Brázda, V.; Paleĉek, J.; Pospísilová, S.; Vojtêsek, B.; Paleĉek, E. Specific modulation of p53 binding to consensus sequence within supercoiled DNA by monoclonal antibodies. Biochem. Biophys. Res. Commun. 2000, 267, 934-939. [CrossRef]

87. Palecek, E.; Brazdova, M.; Brazda, V.; Palecek, J.; Billova, S.; Subramaniam, V.; Jovin, T.M. Binding of p53 and its core domain to supercoiled DNA. Eur. J. Biochem. 2001, 268, 573-581. [CrossRef]

88. Brazdova, M.; Navratilova, L.; Tichy, V.; Nemcova, K.; Lexa, M.; Hrstka, R.; Pecinka, P.; Adamik, M.; Vojtesek, B.; Palecek, E.; et al. Preferential Binding of Hot Spot Mutant p53 Proteins to Supercoiled DNA In Vitro and in Cells. PLoS ONE 2013, 8, e59567. [CrossRef]

89. Mazur, S.J.; Sakaguchi, K.; Appella, E.; Wang, X.W.; Harris, C.C.; Bohr, V.A. Preferential binding of tumor suppressor p53 to positively or negatively supercoiled DNA involves the C-terminal domain. J. Mol. Biol. 1999, 292, 241-249. [CrossRef]

90. Pivonkova, H.; Sebest, P.; Pecinka, P.; Ticha, O.; Nemcova, K.; Brazdova, M.; Jagelska, E.B.; Brazda, V.; Fojta, M. Selective binding of tumor suppressor p53 protein to topologically constrained DNA: Modulation by intercalative drugs. Biochem. Biophys. Res. Commun. 2010, 393, 894-899. [CrossRef]

91. Sandri, M.I.; Isaacs, R.J.; Ongkeko, W.M.; Harris, A.L.; Hickson, I.D.; Broggini, M.; Vikhanskaya, F. p53 regulates the minimal promoter of the human topoisomerase IIalpha gene. Nucleic Acids Res. 1996, 24, 4464-4470. [CrossRef] [PubMed]

92. Jagelska, E.B.; Brazda, V.; Pecinka, P.; Palecek, E.; Fojta, M. DNA topology influences p53 sequence-specific DNA binding through structural transitions within the target sites. Biochem. J. 2008, 412, 57-63. [CrossRef] [PubMed]

93. Carvalho, C.M.B.; Zhang, F.; Lupski, J.R. Structural variation of the human genome: Mechanisms, assays, and role in male infertility. Syst. Biol. Reprod. Mech. 2011, 57, 3-16. [CrossRef] [PubMed]

94. Warburton, P.E.; Giordano, J.; Cheung, F.; Gelfand, Y.; Benson, G. Inverted repeat structure of the human genome: The $\mathrm{X}$-chromosome contains a preponderance of large, highly homologous inverted repeats that contain testes genes. Genome Res. 2004, 14, 1861-1869. [CrossRef]

95. Feuk, L.; Carson, A.R.; Scherer, S.W. Structural variation in the human genome. Nat. Rev. Genet. 2006, 7, 85-97. [CrossRef] 
96. Burger, A.M.; Dai, F.; Schultes, C.M.; Reszka, A.P.; Moore, M.J.; Double, J.A.; Neidle, S. The G-Quadruplex-Interactive Molecule BRACO-19 Inhibits Tumor Growth, Consistent with Telomere Targeting and Interference with Telomerase Function. Cancer Res. 2005, 65, 1489-1496. [CrossRef]

97. Lee, S.; Ho, J.Y.; Liu, J.J.; Lee, H.; Park, J.Y.; Baik, M.; Ko, M.; Lee, S.U.; Choi, Y.J.; Hur, S.Y. CKD-602, a topoisomerase I inhibitor, induces apoptosis and cell-cycle arrest and inhibits invasion in cervical cancer. Mol. Med. 2019, 25, 23. [CrossRef]

98. Zheng, K.-W.; He, Y.; Liu, H.-H.; Li, X.-M.; Hao, Y.-H.; Tan, Z. Superhelicity Constrains a Localized and R-Loop-Dependent Formation of G-Quadruplexes at the Upstream Region of Transcription. ACS Chem. Biol. 2017, 12, 2609-2618. [CrossRef]

99. Lee, S.M.; Cavallo, L.; Griffith, J. Human p53 binds Holliday junctions strongly and facilitates their cleavage. J. Biol. Chem. 1997, 272, 7532-7539. [CrossRef]

100. Subramanian, D.; Griffith, J.D. p53 Monitors replication fork regression by binding to "chickenfoot" intermediates. J. Biol. Chem. 2005, 280, 42568-42572. [CrossRef]

101. Stansel, R.M.; Subramanian, D.; Griffith, J.D. p53 binds telomeric single strand overhangs and t-loop junctions in vitro. J. Biol. Chem. 2002, 277, 11625-11628. [CrossRef] [PubMed]

102. Stros, M.; Muselikova-Polanska, E.; Pospisilova, S.; Strauss, F. High-affinity binding of tumor-suppressor protein p53 and HMGB1 to hemicatenated DNA loops. Biochemistry 2004, 43, 7215-7225. [CrossRef] [PubMed]

103. Brazda, V.; Laister, R.C.; Jagelska, E.B.; Arrowsmith, C. Cruciform structures are a common DNA feature important for regulating biological processes. BMC Mol. Biol. 2011, 12, 33. [CrossRef] [PubMed]

104. Coufal, J.; Jagelska, E.B.; Liao, J.C.C.; Brazda, V. Preferential binding of p53 tumor suppressor to p21 promoter sites that contain inverted repeats capable of forming cruciform structure. Biochem. Biophys. Res. Commun. 2013, 441, 83-88. [CrossRef] [PubMed]

105. Čechová, J.; Coufal, J.; Jagelská, E.B.; Fojta, M.; Brázda, V. p73, like its p53 homolog, shows preference for inverted repeats forming cruciforms. PLoS ONE 2018, 13, e0195835. [CrossRef] [PubMed]

106. Brazda, V.; Cechova, J.; Battistin, M.; Coufal, J.; Jagelska, E.B.; Raimondi, I.; Inga, A. The structure formed by inverted repeats in 553 response elements determines the transactivation activity of p53 protein. Biochem. Biophys. Res. Commun. 2017, 483, 516-521. [CrossRef]

107. Petr, M.; Helma, R.; Polaskova, A.; Krejci, A.; Dvorakova, Z.; Kejnovska, I.; Navratilova, L.; Adamik, M.; Vorlickova, M.; Brazdova, M. Wild-type p53 binds to MYC promoter G-quadruplex. Biosci. Rep. 2016, 36, e00397. [CrossRef]

108. Adamik, M.; Kejnovska, I.; Bazantova, P.; Petr, M.; Renciuk, D.; Vorlickova, M.; Brazdova, M. p53 binds human telomeric G-quadruplex in vitro. Biochimie 2016, 128, 83-91. [CrossRef]

109. Lee, S.-H.; Siaw, G.E.-L.; Willcox, S.; Griffith, J.D.; Hsieh, T.-S. Synthesis and dissolution of hemicatenanes by type IA DNA topoisomerases. Proc. Natl. Acad. Sci. USA 2013, 110, E3587-E3594. [CrossRef]

110. Bush, N.G.; Evans-Roberts, K.; Maxwell, A. DNA Topoisomerases. EcoSal Plus 2015, 6. [CrossRef]

111. Lee, S.-J.; No, Y.R.; Dang, D.T.; Dang, L.H.; Yang, V.W.; Shim, H.; Yun, C.C. Regulation of Hypoxia-inducible Factor 1 alpha (HIF-1 alpha) by Lysophosphatidic Acid Is Dependent on Interplay between p53 and Kruppel-like Factor 5. J. Biol. Chem. 2013, 288, 25244-25253. [CrossRef] [PubMed]

112. Stros, M.; Ozaki, T.; Bacikova, A.; Kageyama, H.; Nakagawara, A. HMGB1 and HMGB2 cell-specifically down-regulate the p53- and p73- dependent sequence-specific transactivation from the human Bax gene promoter. J. Biol. Chem. 2002, 277, 7157-7164. [CrossRef] [PubMed]

113. Griffith, J.D.; Comeau, L.; Rosenfield, S.; Stansel, R.M.; Bianchi, A.; Moss, H.; de Lange, T. Mammalian telomeres end in a large duplex loop. Cell 1999, 97, 503-514. [CrossRef]

114. Kar, A.; Willcox, S.; Griffith, J.D. Transcription of telomeric DNA leads to high levels of homologous recombination and t-loops. Nucleic Acids Res. 2016, 44, 9369-9380. [CrossRef] [PubMed]

115. Stansel, R.M.; de Lange, T.; Griffith, J.D. T-loop assembly in vitro involves binding of TRF2 near the $3^{\prime}$ telomeric overhang. EMBO J. 2001, 20, 5532-5540. [CrossRef] [PubMed]

116. Tutton, S.; Azzam, G.A.; Stong, N.; Vladimirova, O.; Wiedmer, A.; Monteith, J.A.; Beishline, K.; Wang, Z.; Deng, Z.; Riethman, H.; et al. Subtelomeric p53 binding prevents accumulation of DNA damage at human telomeres. EMBO J. 2016, 35, 193-207. [CrossRef]

117. Lieberman, P.M. Retrotransposon-derived p53 binding sites enhance telomere maintenance and genome protection. Bioessays 2016, 38, 943-949. [CrossRef] 
118. Frank-Kamenetskii, M.D.; Mirkin, S.M. Triplex DNA structures. Annu. Rev. Biochem 1995, 64, 65-95. [CrossRef]

119. Li, Y.; Syed, J.; Sugiyama, H. RNA-DNA Triplex Formation by Long Noncoding RNAs. Cell Chem. Biol. 2016, 23, 1325-1333. [CrossRef]

120. Thomas, T.J.; Faaland, C.A.; Gallo, M.A.; Thomas, T. Suppression of c-myc oncogene expression by a polyamine-complexed triplex forming oligonucleotide in MCF-7 breast cancer cells. Nucleic Acids Res. 1995, 23, 3594-3599. [CrossRef]

121. Zhang, S.; Wu, Y.; Zhang, W. G-quadruplex structures and their interaction diversity with ligands. ChemMedChem 2014, 9, 899-911. [CrossRef] [PubMed]

122. Day, H.A.; Pavlou, P.; Waller, Z.A.E. i-Motif DNA: Structure, stability and targeting with ligands. Bioorg. Med. Chem. 2014, 22, 4407-4418. [CrossRef] [PubMed]

123. Kumar, N.; Maiti, S. A thermodynamic overview of naturally occurring intramolecular DNA quadruplexes. Nucleic Acids Res. 2008, 36, 5610-5622. [CrossRef] [PubMed]

124. Lane, A.N.; Chaires, J.B.; Gray, R.D.; Trent, J.O. Stability and kinetics of G-quadruplex structures. Nucleic Acids Res. 2008, 36, 5482-5515. [CrossRef]

125. Neidle, S.; Parkinson, G.N. Quadruplex DNA crystal structures and drug design. Biochimie 2008, 90, 1184-1196. [CrossRef]

126. Neidle, S. The structures of quadruplex nucleic acids and their drug complexes. Curr. Opin. Struct. Biol. 2009, 19, 239-250. [CrossRef]

127. Rhodes, D.; Lipps, H.J. G-quadruplexes and their regulatory roles in biology. Nucleic Acids Res. 2015, 43, 8627-8637. [CrossRef]

128. Haronikova, L.; Coufal, J.; Kejnovska, I.; Jagelska, E.B.; Fojta, M.; Dvorakova, P.; Muller, P.; Vojtesek, B.; Brazda, V. IFI16 Preferentially Binds to DNA with Quadruplex Structure and Enhances DNA Quadruplex Formation. PLoS ONE 2016, 11, e0157156. [CrossRef]

129. Kharel, P.; Balaratnam, S.; Beals, N.; Basu, S. The role of RNA G-quadruplexes in human diseases and therapeutic strategies. Wiley Interdiscip. Rev. RNA 2019, e1568. [CrossRef]

130. Gomes, A.S.; Trovão, F.; Andrade Pinheiro, B.; Freire, F.; Gomes, S.; Oliveira, C.; Domingues, L.; Romão, M.J.; Saraiva, L.; Carvalho, A.L. The Crystal Structure of the R280K Mutant of Human p53 Explains the Loss of DNA Binding. Int. J. Mol. Sci. 2018, 19, 1184. [CrossRef]

131. Oren, M.; Rotter, V. Mutant p53 Gain-of-Function in Cancer. Cold Spring Harb. Perspect. Biol. 2010, 2 , a001107. [CrossRef] [PubMed]

132. Vaughan, C.; Pearsall, I.; Yeudall, A.; Deb, S.P.; Deb, S. p53: Its mutations and their impact on transcription. Subcell. Biochem. 2014, 85, 71-90. [PubMed]

133. Brazda, V.; Muller, P.; Brozkova, K.; Vojtesek, B. Restoring wild-type conformation and DNA-binding activity of mutant $\mathrm{p} 53$ is insufficient for restoration of transcriptional activity. Biochem. Biophys. Res. Commun. 2006, 351, 499-506. [CrossRef] [PubMed]

134. Viadiu, H.; Fronza, G.; Inga, A. Structural studies on mechanisms to activate mutant p53. Subcell. Biochem. 2014, 85, 119-132.

135. Quante, T.; Otto, B.; Brazdova, M.; Kejnovska, I.; Deppert, W.; Tolstonog, G.V. Mutant p53 is a transcriptional co-factor that binds to G-rich regulatory regions of active genes and generates transcriptional plasticity. Cell Cycle 2012, 11, 3290-3303. [CrossRef]

136. Brazdova, M.; Quante, T.; Toegel, L.; Walter, K.; Loscher, C.; Tichy, V.; Cincarova, L.; Deppert, W.; Tolstonog, G.V. Modulation of gene expression in U251 glioblastoma cells by binding of mutant p53 $\mathrm{R} 273 \mathrm{H}$ to intronic and intergenic sequences. Nucleic Acids Res. 2009, 37, 1486-1500. [CrossRef]

137. Sampath, J.; Sun, D.X.; Kidd, V.J.; Grenet, J.; Gandhi, A.; Shapiro, L.H.; Wang, Q.J.; Zambetti, G.P.; Schuetz, J.D. Mutant p53 cooperates with ETS and selectively up-regulates human MDR1 not MRP1. J. Biol. Chem. 2001, 276, 39359-39367. [CrossRef]

138. Chicas, A.; Molina, P.; Bargonetti, J. Mutant p53 forms a complex with Sp1 on HIV-LTR DNA. Biochem. Biophys. Res. Commun. 2000, 279, 383-390. [CrossRef]

139. Brazda, V.; Haronikova, L.; Liao, J.C.C.; Fojta, M. DNA and RNA Quadruplex-Binding Proteins. Int. J. Mol. Sci. 2014, 15, 17493-17517. [CrossRef] 
140. Ramos, E.M.; Gillis, T.; Mysore, J.S.; Lee, J.M.; Alonso, I.; Gusella, J.F.; Smoller, J.W.; Sklar, P.; MacDonald, M.E.; Perlis, R.H. Prevalence of Huntington's disease gene CAG trinucleotide repeat alleles in patients with bipolar disorder. Bipolar Disord. 2015, 17, 403-408. [CrossRef]

141. Den Dunnen, W.F.A. Trinucleotide repeat disorders. In Handbook of Clinical Neurology; Elsevier B.V.: Oxford, UK, 2017; Volume 145, pp. 383-391.

142. Pearson, C.E.; Sinden, R.R. Trinucleotide repeat DNA structures: Dynamic mutations from dynamic DNA. Curr. Opin. Struct. Biol. 1998, 8, 321-330. [CrossRef]

143. Beaver, J.M.; Lai, Y.; Rolle, S.J.; Liu, Y. Proliferating cell nuclear antigen prevents trinucleotide repeat expansions by promoting repeat deletion and hairpin removal. DNA Repair 2016, 48, 17-29. [CrossRef] [PubMed]

144. Pearson, C.E.; Zorbas, H.; Price, G.B.; ZannisHadjopoulos, M. Inverted repeats, stem-loops, and cruciforms: Significance for initiation of DNA replication. J. Cell. Biochem. 1996, 63, 1-22. [CrossRef]

145. Brázda, V.; Coufal, J.; Liao, J.C.C.; Arrowsmith, C.H. Preferential binding of IFI16 protein to cruciform structure and superhelical DNA. Biochem. Biophys. Res. Commun. 2012, 422, 716-720. [CrossRef] [PubMed]

146. van Holde, K.; Zlatanova, J. Unusual DNA structures, chromatin and transcription. Bioessays 1994, 16, 59-68. [CrossRef] [PubMed]

147. Kim, E.; Rohaly, G.; Heinrichs, S.; Gimnopoulos, D.; Meissner, H.; Deppert, W. Influence of promoter DNA topology on sequence-specific DNA binding and transactivation by tumor suppressor p53. Oncogene 1999, 18, 7310-7318. [CrossRef]

148. Saramaki, A.; Banwell, C.M.; Campbell, M.J.; Carlberg, C. Regulation of the human p21 (waf1/cip1) gene promoter via multiple binding sites for $\mathrm{p} 53$ and the vitamin D-3 receptor. Nucleic Acids Res. 2006, 34, 543-554. [CrossRef]

149. Jett, S.D.; Cherny, D.I.; Subramaniam, V.; Jovin, T.M. Scanning force microscopy of the complexes of p53 core domain with supercoiled DNA. J. Mol. Biol. 2000, 299, 585-592. [CrossRef]

150. Cherny, D.I.; Striker, G.; Subramaniam, V.; Jett, S.D.; Palecek, E.; Jovin, T.M. DNA bending due to specific p53 and p53 core domain-DNA interactions visualized by electron microscopy. J. Mol. Biol. 1999, 294, 1015-1026. [CrossRef]

151. Moore, L.D.; Le, T.; Fan, G. DNA methylation and its basic function. Neuropsychopharmacology 2013, 38, 23-38. [CrossRef]

152. Stillman, B. Histone Modifications: Insights into Their Influence on Gene Expression. Cell 2018, 175, 6-9. [CrossRef] [PubMed]

153. Holoch, D.; Moazed, D. RNA-mediated epigenetic regulation of gene expression. Nat. Rev. Genet. 2015, 16, 71-84. [CrossRef] [PubMed]

154. Chen, Z.; Li, S.; Subramaniam, S.; Shyy, J.Y.-J.; Chien, S. Epigenetic Regulation: A New Frontier for Biomedical Engineers. Annu. Rev. Biomed. Eng. 2017, 19, 195-219. [CrossRef] [PubMed]

155. Bao, F.; LoVerso, P.R.; Fisk, J.N.; Zhurkin, V.B.; Cui, F. p53 binding sites in normal and cancer cells are characterized by distinct chromatin context. Cell Cycle 2017, 16, 2073-2085. [CrossRef] [PubMed]

156. Nabilsi, N.H.; Ryder, D.J.; Peraza-Penton, A.C.; Poudyal, R.; Loose, D.S.; Kladde, M.P. Local depletion of DNA methylation identifies a repressive p53 regulatory region in the NEK2 promoter. J. Biol. Chem. 2013, 288, 35940-35951. [CrossRef] [PubMed]

157. Sammons, M.A.; Zhu, J.; Drake, A.M.; Berger, S.L. TP53 engagement with the genome occurs in distinct local chromatin environments via pioneer factor activity. Genome Res. 2015, 25, 179-188. [CrossRef] [PubMed]

158. Yu, X.; Buck, M.J. Defining TP53 pioneering capabilities with competitive nucleosome binding assays. Genome Res. 2019, 29, 107-115. [CrossRef]

159. Taube, J.H.; Allton, K.; Duncan, S.A.; Shen, L.; Barton, M.C. Foxa1 functions as a pioneer transcription factor at transposable elements to activate Afp during differentiation of embryonic stem cells. J. Biol. Chem. 2010, 285, 16135-16144. [CrossRef]

160. Zhabinskaya, D.; Benham, C.J. Competitive superhelical transitions involving cruciform extrusion. Nucleic Acids Res. 2013, 41, 9610-9621. [CrossRef]

161. Drolet, M. Growth inhibition mediated by excess negative supercoiling: The interplay between transcription elongation, R-loop formation and DNA topology. Mol. Microbiol. 2006, 59, 723-730. [CrossRef]

162. Krasilnikov, A.S.; Podtelezhnikov, A.; Vologodskii, A.; Mirkin, S.M. Large-scale effects of transcriptional DNA supercoiling in vivo. J. Mol. Biol. 1999, 292, 1149-1160. [CrossRef] [PubMed] 
163. Schiavone, D.; Guilbaud, G.; Murat, P.; Papadopoulou, C.; Sarkies, P.; Prioleau, M.-N.; Balasubramanian, S.; Sale, J.E. Determinants of G quadruplex-induced epigenetic instability in REV1-deficient cells. EMBO J. 2014, 33, 2507-2520. [CrossRef] [PubMed]

164. Guilbaud, G.; Murat, P.; Recolin, B.; Campbell, B.C.; Maiter, A.; Sale, J.E.; Balasubramanian, S. Local epigenetic reprogramming induced by G-quadruplex ligands. Nat. Chem. 2017, 9, 1110-1117. [CrossRef] [PubMed]

165. Allers, T.; Leach, D.R. DNA palindromes adopt a methylation-resistant conformation that is consistent with DNA cruciform or hairpin formation in vivo. J. Mol. Biol. 1995, 252, 70-85. [CrossRef] [PubMed]

166. Jara-Espejo, M.; Peres Line, S.R. DNA G-quadruplex stability, position and chromatin accessibility are associated with CpG island methylation. FEBS J. 2019. [CrossRef]

167. Schlereth, K.; Heyl, C.; Krampitz, A.-M.; Mernberger, M.; Finkernagel, F.; Scharfe, M.; Jarek, M.; Leich, E.; Rosenwald, A.; Stiewe, T. Characterization of the p53 cistrome-DNA binding cooperativity dissects p53's tumor suppressor functions. PLoS Genet. 2013, 9, e1003726. [CrossRef]

168. Stiewe, T.; Haran, T.E. How mutations shape p53 interactions with the genome to promote tumorigenesis and drug resistance. Drug Resist. Updat. 2018, 38, 27-43. [CrossRef]

169. Ohtsuka, J.; Oshima, H.; Ezawa, I.; Abe, R.; Oshima, M.; Ohki, R. Functional loss of p53 cooperates with the in vivo microenvironment to promote malignant progression of gastric cancers. Sci. Rep. 2018, 8, 2291. [CrossRef]

170. Nakayama, M.; Sakai, E.; Echizen, K.; Yamada, Y.; Oshima, H.; Han, T.-S.; Ohki, R.; Fujii, S.; Ochiai, A.; Robine, S.; et al. Intestinal cancer progression by mutant p53 through the acquisition of invasiveness associated with complex glandular formation. Oncogene 2017, 36, 5885-5896. [CrossRef]

171. Iyer, S.V.; Parrales, A.; Begani, P.; Narkar, A.; Adhikari, A.S.; Martinez, L.A.; Iwakuma, T. Allele-specific silencing of mutant p53 attenuates dominant-negative and gain-of-function activities. Oncotarget 2016, 7, 5401-5415. [CrossRef]

172. Parrales, A.; Ranjan, A.; Iyer, S.V.; Padhye, S.; Weir, S.J.; Roy, A.; Iwakuma, T. DNAJA1 controls the fate of misfolded mutant p53 through the mevalonate pathway. Nat. Cell Biol. 2016, 18, 1233-1243. [CrossRef] [PubMed]

173. Joruiz, S.M.; Bourdon, J.-C. p53 Isoforms: Key Regulators of the Cell Fate Decision. Cold Spring Harb. Perspect. Med. 2016, 6, a026039. [CrossRef] [PubMed]

174. Bischof, K.; Knappskog, S.; Hjelle, S.M.; Stefansson, I.; Woie, K.; Salvesen, H.B.; Gjertsen, B.T.; Bjorge, L. Influence of p53 Isoform Expression on Survival in High-Grade Serous Ovarian Cancers. Sci. Rep. 2019, 9, 5244. [CrossRef] [PubMed] 